\title{
Photosynthesis and gas exchanges of forage cactus varieties (Opuntia and Nopalea) grown under screen and irrigation
}

\author{
Fotossintese e trocas gasosas de variedades de palma forrageira \\ (Opuntia e Nopalea) cultivadas sob telado e irrigação
}

IInstituto Agronômico de Pernambuco (IPA), Av. General San Martin, 1371, Bongi, CEP 50761-000, Recife, PE, Brasil

*autor correspondente 凹abel.alves@ipa.br

Francisco Abel Lemos Alves ${ }^{1 *}$, Djalma Cordeiro dos Santos ${ }^{1}$, Sérvulo Mercier Siqueira e Silva ${ }^{1}$ Marciano Arcanjo Barbosa Oliveira

ABSTRACT: Forage cactus is a CAM-optional plant according to its water status. The objective of this study was to characterize the net photosynthesis rate $(\mathrm{Pn})$, transpiration rate $(\mathrm{E})$, stomatal conductance (C), internal $\mathrm{CO}_{2}$ concentration $\left(\mathrm{CO}_{2 \text { int. }}\right)$, water use efficiency (WUE) and instantaneous carboxylation efficiency $(\mathrm{CE} i)$ of forage cactus varieties of the genus Opuntia and Nopalea grown in the Brazilian semiarid region under screen conditions and periodic irrigation. The study was conducted at the Instituto Agronômico de Pernambuco (IPA) in Arcoverde-PE, during a two-year period (from 2015 to 2017). The plants were arranged in a completely randomized design with four replications. Cultivation was carried out at $1.00 \mathrm{~m} \times 0.20 \mathrm{~m}$ spacing in an area of $4.00 \mathrm{~m}^{2}$ (five lines $0.80 \mathrm{~m}$ long). The varieties IPA-200016 (O. stricta), IPA-100003 (O. ficus - indica), IPA-200008 (O. atropes), IPA-200149 (O. larreri) and IPA-100004 (N. cochenillifera) were grown under screen conditions, with $50 \%$ light reduction, and irrigated every seven days using $1 / 3$ of total weekly evapotranspiration. Measurements were made in all cladodes, on two-year-old plants, at 6:00 a.m., 12:00 p.m., 6:00 p.m. and 0:00 a.m. with the aid of CIDBio-Science Ultra-Light CI-340®. All variables analyzed varied between genotypes and times. The varieties had the same pattern for $P n, E, C, C O_{2 i n t}, W U E$ and $C E i$. Gas exchange takes place during the day time (optional-CAM). Assimilation of $\mathrm{CO}_{2}$ predominates at night (CAM). The loss of $\mathrm{H}_{2} \mathrm{O}$ is most evident during the day (C3). Stomatal conductance is identical to those reported for C3 and C4 plants. The IPA-200149 variety stands out in relation to WUE and $\mathrm{CEi}$ related to the others.

KEYWORDS: Abiotic stresses, crassulacean acid metabolism-CAM, $\mathrm{CO}_{2}$ assimilation, photosynthesis-carboxylation.
RESUMO: A palma forrageira é uma planta CAM-facultativa, dependendo do seu status hídrico. O objetivo deste estudo foi caracterizar a taxa de fotossintese líquida, taxa de transpiração, condutância estomática, concentração interna de $\mathrm{CO}_{2}$, eficiência do uso da água e eficiência instantânea de carboxilação de variedades de palma forrageira dos gêneros Opuntia e Nopalea cultivadas na região semiárida do Brasil, sob condições de telado e irrigação periódica. O estudo foi conduzido no Instituto Agronômico de Pernambuco (IPA) em Arcoverde-PE, durante o periodo de dois anos (2015 a 2017). As plantas foram dispostas em delineamento inteiramente casualizado, com quatro repetições. $O$ cultivo foi realizado no espaçamento $1,00 \mathrm{~m} \times 0,20 \mathrm{~m}$ em uma área de $4,00 \mathrm{~m}^{2}$ (cinco linhas de 0,80 m de comprimento). As variedades IPA-200016 (O. stricta), IPA-100003 (O. ficus - indica), IPA-200008 (O. atropes), IPA-200149 (O. larreri) e IPA-100004 (N. cochenillifera) foram cultivadas sob condições de telado, com redução da luminosidade de $50 \%$ e irrigadas a cada sete dias, com 1/3 da evapotranspiração total semanal. Foram determinadas nos cladódios de plantas com dois anos de idade, a taxa de fotossíntese líquida $(P n)$, taxa de transpiração (E), taxa de condutância estomática $(C)$, taxa de concentração interna de $\mathrm{CO}_{2}\left(\mathrm{CO}_{2 i n t}\right)$, eficiência no uso da água (EUA) e eficiência instantânea de carboxilação (EiC). As medições foram feitas, em todos os cladódios, às 6:00, 12:00, 18:00 e 24:00 horas, com o auxílio do aparelho Ultra-Light CI-340®, da CIDBio-Science. Todas as variáveis analisadas variam entre genótipos e horários. As variedades tiveram o mesmo padrão de Pn, E, C, CO ${ }_{2 i n t}$, EUA e EiC. As trocas gasosas acontecem diuturnamente (CAM-facultativa). A assimilação de $\mathrm{CO}_{2}$ predomina à noite (CAM). A perda de $\mathrm{H}_{2} \mathrm{O}$ é mais evidente durante o dia (C3). A C sucede-se de modo idêntico aos relatados para plantas C3 e C4. A variedade IPA-200149 se destaca na EUA e EiC, em comparação às outras.

PALAVRAS-CHAVE: Estresses abióticos, metabolismo ácido das crassuláceas-CAM, assimilação de $\mathrm{CO}_{2}$, fotossíntese-carboxilação. 


\section{Introduction}

The brazilian semiarid region is characterized by high daytime temperatures, and in some places, low night temperatures, high solar radiation, low air humidity, low, infrequent, unpredictable and random rainfall, which concentrate on few months. Most soils are shallow, with low water storage capacity, low $\mathrm{pH}$ (acidic) values, insufficient drainage, and salinized in some places, besides low availability of some essential nutrients for plant growth and development. All of these characteristics limit the cultivation of some plant species (ALVES et al., 2017).

Therefore, water availability in this region is a limiting factor to the growth and development of plants and living beings in general. However, plant species of Opuntia and Nopalea genera adapt very well to these environments. These plants have anatomical, morphological, physiological and biochemical characteristics that allow them to absorb and accumulate water in their tissues from the most insignificant rain or dew, and reduce water loss to a minimum while maintaining cell turgor (OLIVEIRA et al., 2010).

It is estimated that in Brazil there are approximately 147,439 ha cultivated with forage palm species Opuntia ficus - indica (cv. Gigante, Redonda and IPA clone 20), Opuntia stricta (cv. Mexican Elephant Ear) and Nopalea cochenillifera (cv. Miúda and IPA-Sertânia), in which about 145,781 ha concentrated in the semiarid region of the Northeast, and intended exclusively for animal feeding, especially in the dry months of the year (INSTITUTO BRASILEIRO DE GEOGRAFIA E ESTATISTICA, 2019; ALVES et al., 2016).

These plants possess the Crassulacean Acid-CAM photosynthetic metabolism, where they open their stomata at night, when temperatures are milder, to capture and fix $\mathrm{CO}_{2}$ in four-carbon acids; and the subsequent incorporation of $\mathrm{CO}_{2}$ into carbon skeletons during the day when the temperature is high and their stomata are closed, therefore, avoiding water loss, and thus increasing photosynthetic efficiency and water use (TAIZ et al., 2017).

Recent studies reports that some CAM-metabolism plants according to their water status, can turn into optional-CAM (LIGUORI et al., 2013). These plants use CAM metabolism when water is scarce, but make a gradual transition to $\mathrm{C}_{3}$ photosynthetic metabolism when water becomes abundant (WINTER et al., 2011).

The hypothesis of paper is to state that forage palm plants have $\mathrm{C}_{3}$ photosynthetic metabolism when water becomes abundant. Thus, the objective of this study was to characterize the net photosynthesis rate, transpiration rate, stomatal conductance, internal $\mathrm{CO}_{2}$ concentration, water use efficiency and instantaneous carboxylation efficiency of forage palm varieties of the genus Opuntia and Nopalea grown in the semiarid region of Brazil, under screen conditions and periodic irrigation.

\section{Material and Methods}

The study was conducted at the experimental station owned by Pernambuco Agronomic Institute (IPA - Instituto Agronômico de Pernambuco), located in the municipality of Arcoverde,
Pernambuco, Brazil, for the period of two years (november 2015 to december 2017).

Forage cactus varieties, Mexican Elephant Ear - IPA-200016 (Opuntia stricta), IPA clone 20 - IPA-100003 (Opuntia ficus - indica), F-08 - IPA-200008 (Opuntia atropes), V-19 - IPA200149 (Opuntia larreri) and IPA-100004 (N. cochenillifera) were grown in a spacing of $1.00 \mathrm{~m}$ between rows and $0.20 \mathrm{~m}$ between plants in an area of $4.00 \mathrm{~m}^{2}$ (five rows of $0.80 \mathrm{~m}$ of length), under screen conditions, with 50\% light reduction. The clones were obtained from the institute's own forage cactus Germplasm Bank-BAG, where a cladode per furrow was used at planting.

The plants were irrigated every 7 (seven) days, using $1 / 3$ of the total weekly evapotranspiration, using a plastic watering can with a capacity of 10 liters of water (QUEIROZ et al., 2016). Plants were fertilized with 20 t.ha $^{-1}$ of cattle manure, applied to the soil, between the rows in the implementation of the experiment and every year. The determination of daily variation in environment air temperature $\left(T_{\text {air }}\right)$, cladode temperature $\left(T_{\text {leaf }}\right)$, active photosynthetic radiation (APR), net photosynthesis rate $(\mathrm{Pn})$, transpiration rate $(\mathrm{E})$, stomatal conductance rate $(\mathrm{C})$, internal $\mathrm{CO}_{2}$ concentration rate $\left(\mathrm{CO}_{2 \text { int. }}\right)$, water use efficiency (WUE) $(\mathrm{Pn} / \mathrm{E})$ and instantaneous carboxylation efficiency (CEi) $(\mathrm{Pn} / \mathrm{CO} 2$ int.) were performed on the primary, secondary, tertiary and quaternary cladodes of two-year old plants. The determinations were made in November and December of 2017, at 6:00 a.m., 12:00 p.m., 6:00 p.m. and 0:00 a.m.

The gadget used to determine these parameters was the CIDBio-Science Ultra-Light Portable Photosynthesis System CI-340®. The camera used was produced by CIDBio-Science, especially for measurement in forage cactus cladodes, with an area of $14.70 \mathrm{~cm}^{2}$. The system used in the study was open, with air flow rate of $0.30 \mathrm{~L} \cdot \mathrm{min}^{-1}$ at pressure of $93.77 \mathrm{kPa}$ and mass flow rate of $0.13 \mathrm{~mol} \cdot \mathrm{m}^{-2} \cdot \mathrm{s}^{-1}$.

The equations of the determined parameters are as follows:

$W=\frac{V}{60} \times \frac{273.15}{T a} \times \frac{P}{1.013} \times \frac{1}{22.41} \times \frac{10000}{A}=2005.39 \times \frac{V \times P}{\operatorname{Ta} \times A}$

where: $W$ : mass flow rate per leaf area $\left(\mathrm{mol} / \mathrm{m}^{2} / \mathrm{s}\right) ; V$ : volume flow rate (liters/minute); $T a$ : air temperature (K); $P$ : atmospheric pressure (bar); $A$ : leaf area $\left(\mathrm{cm}^{2}\right) ; 60$ : converts minutes into seconds; 22.41 : the volume of one mole of any gas at a standard temperature of $273.15 \mathrm{~K}$ and a standard pressure of $1.013 \mathrm{bar}$ (liters/mol); 10000: converts $\mathrm{cm}^{2}$ into $\mathrm{m}^{2}$.

$P n=-W x(C 0-C i)=-2005.39 \times \frac{V \times P}{\operatorname{TaxA}} \times(C 0-C i)$

where: $P n$ : net photosynthesis rate $\left(\mu \mathrm{mol} / \mathrm{m}^{2} / \mathrm{s}\right) ; C 0(C i)$ : outlet (inlet) $\mathrm{CO}_{2}$ concentration (ppm or $\mu \mathrm{mol} / \mathrm{mol}$ ).

$E=\frac{e 0-e i}{P-e 0} \times W \times 10^{3}$

$e 0=\frac{\text { hroxes }}{100}$

$e i=\frac{\text { hrixes }}{100}$ 
$e s=6.13753 \times 10^{-3} x e^{\operatorname{ta} x \frac{18.564-\frac{t a}{254.4}}{t a+255.57}}$

where: $E$ : transpiration rate $\left(\mathrm{mmol} / \mathrm{m}^{2} / \mathrm{s}\right) ; e 0(e i)$ : outlet (inlet) water vapor (bar); $P$ : atmospheric pressure (bar); es: saturated water vapor at air temperature (bar); Ta: air temperature $\left({ }^{\circ} \mathrm{C}\right)$; hro (hri): outlet (inlet) relative humidity $(\%)$.

$$
\begin{aligned}
& \text { Cleaf }=\frac{W}{\frac{\text { eleaf }-e 0}{e 0-e i} \times \frac{P-e 0}{P}-R b W} \times 1000 \\
& \text { eleaf }=6.13753 \times 10^{-3} x e^{\text {Tleaf } x \frac{18.564-\frac{\text { Tleaf }}{254.4}}{\text { Tleaf }+255.57}}
\end{aligned}
$$

where: Cleaf: Leaf stomatal conductance $\left(\mathrm{mmol} / \mathrm{m}^{2} / \mathrm{s}\right)$; eleaf: saturated water vapor at leaf temperature (bar); Tleaf: leaf temperature $\left({ }^{\circ} \mathrm{C}\right) ; R b$ : leaf boundary layer resistance $\left(\mathrm{m}^{2} \mathrm{~s} / \mathrm{mol}\right)$. $0.3 \mathrm{~m}^{2} \mathrm{~s} / \mathrm{mol}$ is used.

$\mathrm{CO}_{2}$ int.$=\mathrm{Ci}-1.6 \times \mathrm{Pn}(\mathrm{Rb}+$ Rleaf $)$

where: $\mathrm{CO}_{2}$ int.: internal $\mathrm{CO} 2$ (ppm or $\left.\mu \mathrm{mol} / \mathrm{mol}\right)$; Rleaf: leaf stomatal resistance $\left(\mathrm{m}^{2} \mathrm{~s} / \mathrm{mol}\right)$.

The experiment was conducted in a completely randomized design with four replications. The experimental plot consisted of one plant of each variety. The treatments consisted of five forage palm varieties (IPA-200016, IPA-100003, IPA-200008, IPA-200149 and IPA-100004), totaling 20 experimental plots. The data analysis was performed by determining means and standard deviations using the Microsoft ${ }^{\circledR}$ Office 2010 Excel software.

\section{Results and Discussion}

The daily profile of environment air temperature $\left(\mathrm{T}_{\text {air }}\right)$ and cladodes $\left(\mathrm{T}_{\text {leaf }}\right)$, active photosynthetic radiation (APR), net photosynthesis rate $(\mathrm{Pn})$, transpiration rate $(\mathrm{E})$, stomatal conductance rate $(\mathrm{C})$, internal $\mathrm{CO}_{2}$ concentration $\left(\mathrm{CO}_{2 \text { int. }}\right)$, water use efficiency (WUE) and instantaneous carboxylation efficiency (CEi) of forage palm varieties followed the same response pattern. However, the values of these variables vary between hours and among botanical varieties.

$\mathrm{T}_{\text {air }}$ and $\mathrm{T}_{\text {leaf }}$ do not vary significantly between time neither between forage cactus varieties. However, the higher the active photosynthetic radiation, the higher the air and cladode temperature (GÓMEZ et al., 2018). The air and cladode temperature of the IPA-20 forage palm variety was higher than the other varieties at 6:00 a.m. (Figure 1). This probably happened due to the position of the plants inside the screen. These plants were closer to the screen wall.

$\mathrm{T}_{\text {leaf }}$ ranges from $20.5{ }^{\circ} \mathrm{C}(0: 00$ a.m. $)$ to $37.8(12: 00$ p.m.) - IPA-200016; from $20.0{ }^{\circ} \mathrm{C}(0: 00$ a.m.) to 36.5 (12:00 p.m.) - IPA-100003; from $20.9^{\circ} \mathrm{C}(0: 00$ a.m.) to 37.1 (12:00 p.m.) - IPA-200008; from $20.5{ }^{\circ} \mathrm{C}(0: 00$ a.m.) to 35.9 (12:00 p.m.) - IPA-200149; and from $20.7{ }^{\circ} \mathrm{C}(0: 00$ a.m.) to 36.5 (12:00 p.m.) - IPA-100004 (Figure 1). The APR ranges from zero in the dark (6:00 p.m. and 0:00 a.m.) to 237.6 $\mu \mathrm{mol} . \mathrm{m}^{-2} . \mathrm{s}^{-1}$ (12: 00 p.m.) - IPA-200016; $271.2 \mu \mathrm{mol} . \mathrm{m}^{-2} . \mathrm{s}^{-1}$ (12:00 p.m.) - IPA-100003; $136.1 \mu \mathrm{mol} . \mathrm{m}^{-2} . \mathrm{s}^{-1}$ (12:00 p.m.) - IPA-200008; $132.0 \mu \mathrm{mol} . \mathrm{m}^{-2} \mathrm{~s}^{-1}$ (12:00 p.m.) - IPA-200149; and $293.4 \mu \mathrm{mol} . \mathrm{m}^{-2} . \mathrm{s}^{-1}$ (12:00 p.m.) - IPA-100004 (Figure 2).

The $P n$ ranges from $-0.33 \mu \mathrm{mol} . \mathrm{m}^{-2} . \mathrm{s}^{-1}(12: 00 \mathrm{p} . \mathrm{m}$.) to 8.08 $\mu$ mol.m ${ }^{-2} . \mathrm{s}^{-1}$ (0:00 a.m.) - IPA-200016; from $0.33 \mu \mathrm{mol} . \mathrm{m}^{-2} . \mathrm{s}^{-1}$ (12:00 p.m.) to $8.13 \mu \mathrm{mol} . \mathrm{m}^{-2} . \mathrm{s}^{-1}$ (0:00 a.m.) - IPA-100003; from $-0.97 \mu \mathrm{mol} . \mathrm{m}^{-2} . \mathrm{s}^{-1}\left(12: 00\right.$ p.m.) to $3.93 \mu \mathrm{mol} . \mathrm{m}^{-2} . \mathrm{s}^{-1}$ (0:00 a.m.) - IPA-200008; $0.74 \mu \mathrm{mol} . \mathrm{m}^{-2} . \mathrm{s}^{-1}$ (6:00 a.m.) to $8.45 \mu \mathrm{mol} . \mathrm{m}^{-2} . \mathrm{s}^{-1}$ (0:00 a.m.) - IPA-200149; and from $0.56 \mu \mathrm{mol} . \mathrm{m}^{-2} \cdot \mathrm{s}^{-1}(6: 00$ a.m.) to $7.10 \mu \mathrm{mol} . \mathrm{m}^{-2} \cdot \mathrm{s}^{-1}$ (0:00 a.m.) - IPA-100004 (Figure 3).

The net photosynthesis rate was practically the same for all palm varieties. Except for the IPA-200008 which has the lowest rate among the varieties at 0:00 a.m., 12:00 p.m. and 6:00 p.m. In addition, the palm varieties IPA-200149, IPA-200016 and IPA-100003 at 6:00 p.m. had the highest $P n$ compared to the others (Figure 3).

The $P n$ follows the pattern of CAM plants, where maximum $\mathrm{CO}_{2}$ assimilation occurs during the night (phase I), decreases in the early morning (phase II), reaching minimum values at noon (phase III), and increases at the end afternoon (phase IV), reaching maximum values at midnight (Figure 3 ).

The $P n$ values found in this study are in agreement with the results reported by Liguori et al. (2013), when studying the $\mathrm{CO}_{2}$ absorption of forage cactus plants (O. ficus - indica), cv. Gialla, irrigated and not-irrigated at one and two years old, grown in pots, in the city of Palermo, Italy. The maximum average Pn values found in irrigated plants at pot capacity was $6.5 \pm 0.9 \mu \mathrm{mol} . \mathrm{m}^{-2} . \mathrm{s}^{-1}$ between midnight (24 hours) and two o'clock in the morning. After 6:00 p.m., Pn decreases abruptly to values close to zero between 12:00 p.m. and 3:00 p.m., when temperatures are the highest. Although the daytime $\mathrm{CO}_{2}$ net absorption is reduced compared to the night time, it continues with positive values throughout the day, being higher in the early and late afternoon. The soil water content increases the Pn of the plant reaching maximum values of $11.1 \mu \mathrm{mol} . \mathrm{m}^{-2} \cdot \mathrm{s}^{-1}$ (01:00 a.m.) and 2.5 $\mu \mathrm{mol} . \mathrm{m}^{-2} . \mathrm{s}^{-1}$ (8:00 a.m.).

When studying the eco-physiology of forage cactus (O. ficus - indica) grown under dry and irrigated conditions, Pimienta-Barrios et al. (2012) reports that for both conditions, the main period of net $\mathrm{CO}_{2}$ absorption is at night, $84 \%$ (irrigated) and $82 \%$ (dry) of positive $P n$. Daytime $\mathrm{CO}_{2}$ absorption is observed under both conditions (dry and irrigated) in the early morning and late afternoon. However, the reduction occurs over the course of the day, reaching values close to zero between 10:00 a.m. and 4:00 p.m. However, the water status of the plant interferes with the daytime and nightime positive Pn values. Irrigation increases palm $P n$, reaching maximum values of $15 \mu \mathrm{mol} . \mathrm{m}^{-2} . \mathrm{s}^{-1}$ (0:00 a.m.) and $10 \mu \mathrm{mol} . \mathrm{m}^{-2} . \mathrm{s}^{-1}$ (8:00 a.m.).

Most atmospheric capture of $\mathrm{CO}_{2}$ by forage cactus and other CAM plants occurs at night, when active photosynthetic radiation (APR) and/or instantaneous photosynthetic photon flux (PPF) is zero (Figure 2); therefore, the photosynthesis reactions of the tilacoids (light reactions - ATP and NADPH production) are not possible. In contrast, atmospheric $\mathrm{CO}_{2}$ capture and photosynthesis of $\mathrm{C} 3$ and $\mathrm{C} 4$ plants occur simultaneously with light absorption during the day (NOBEL, 2001; TAIZ et al., 2017). 

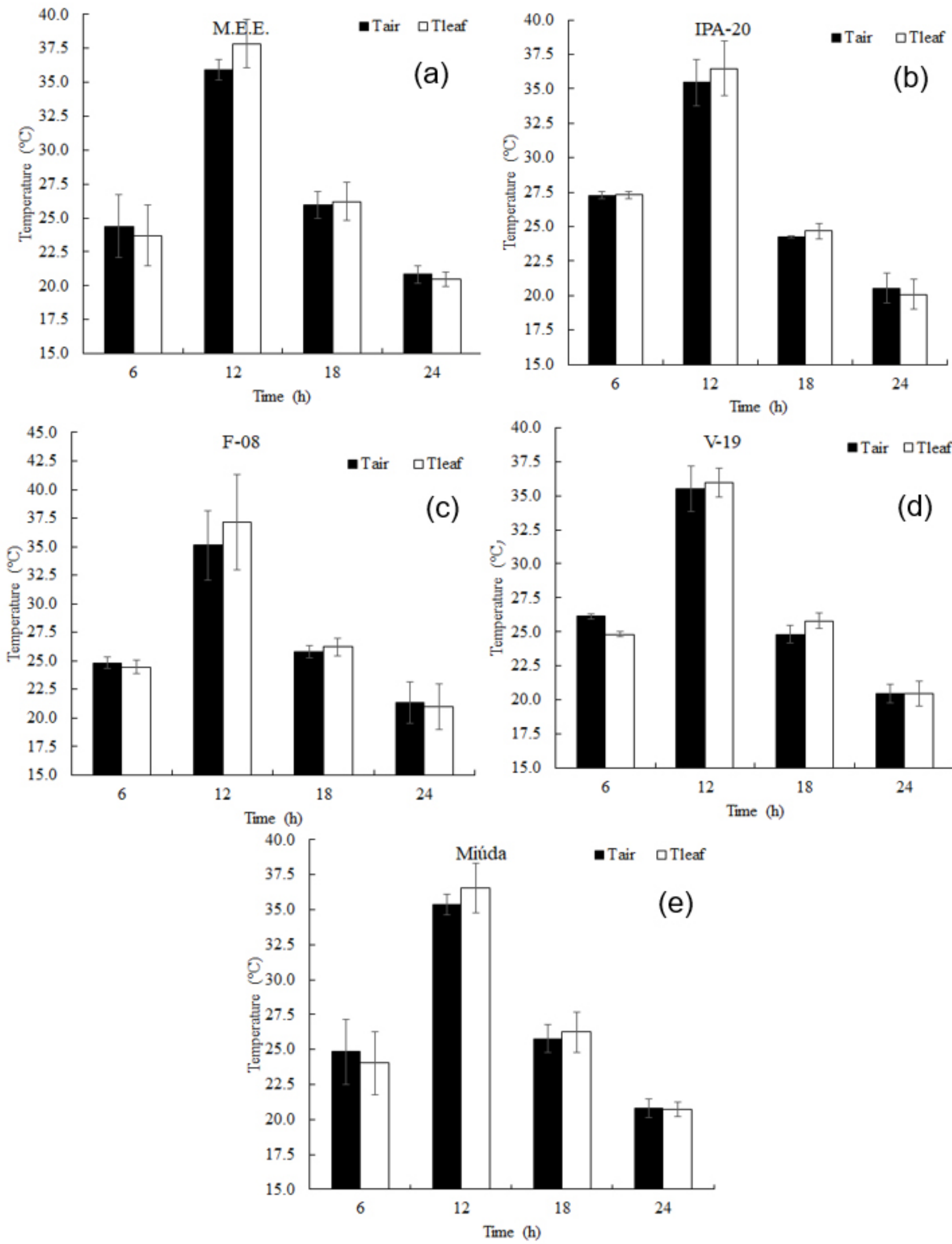

Figure 1. Daily environment air temperature $\left(\mathrm{T}_{\text {air }}\right)$ and cladode temperature $\left(\mathrm{T}_{\text {leaf }}\right)$ of forage cactus varieties Mexican Elephant Ear -M.E.E. - IPA-200016 (O. stricta) (a); IPA clone 20 - IPA-100003 (O. ficus - indica) (b); F-08 - IPA-200008 (O. atropes) (c), V-19 - IPA-200149 (O. larreri) (d) and Miúda - IPA-100004 (N. cochenillifera) (e), grown under screen and irrigation in the municipality of Arcoverde, Pernambuco, Brazil in the period of november and december of 2017. Bars are the mean $(\mathrm{n}=4$ plants $) \pm$ standard deviation. 

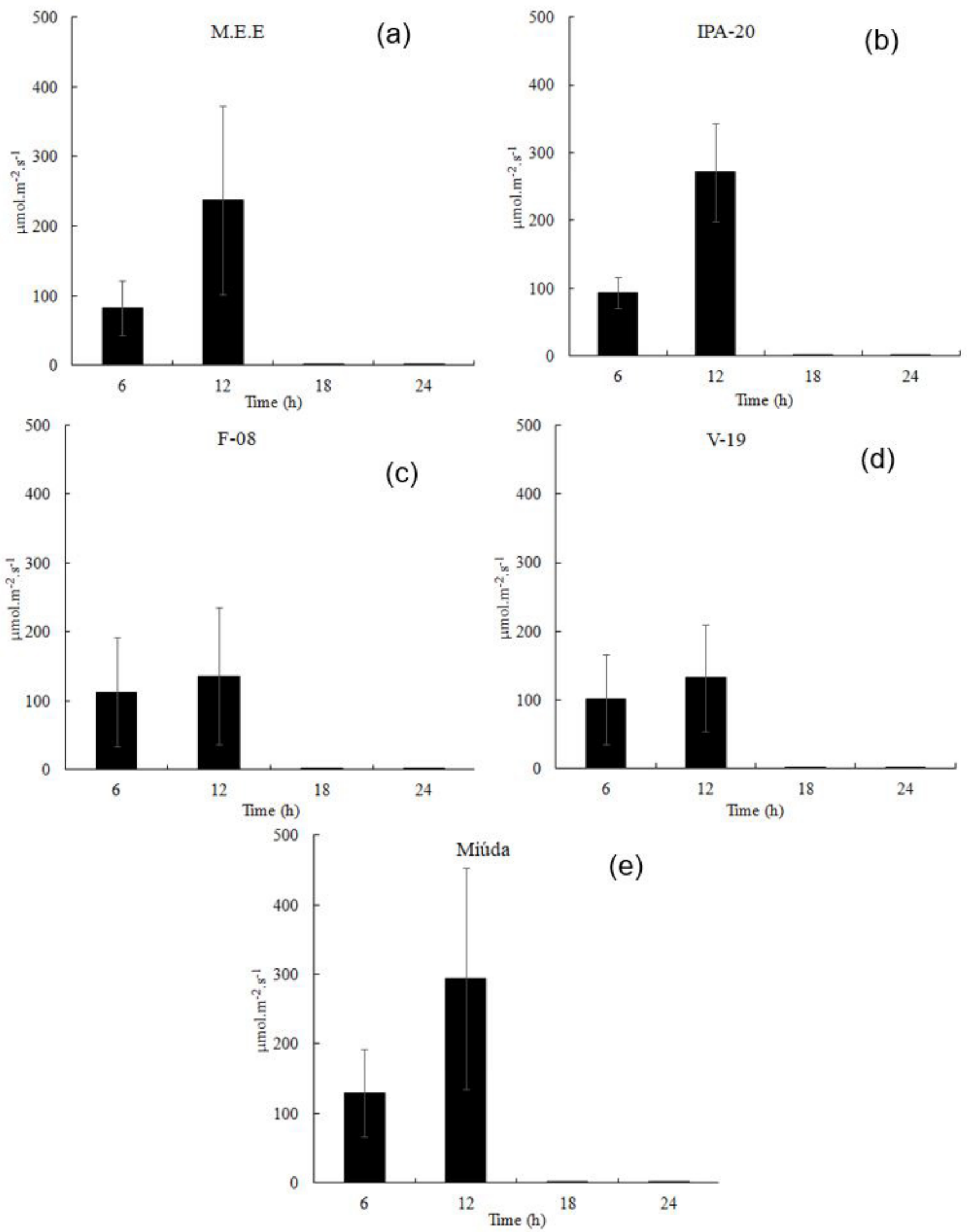

Figure 2. Daily Active Photosynthetic Radiation (APR) of forage cactus varieties Mexican Elephant Ear - M.E.E. - IPA-200016 (O. stricta) (a), IPA clone 20 - IPA- 100003 (O. ficus - indica) (b), F-08 - IPA-200008 (O. atropes) (c), V-19 - IPA-200149 (O. larreri) (d) and Miúda - IPA-100004 (N. cochenillifera) (e), grown under screen and irrigation, in the municipality of Arcoverde, Pernambuco, Brazil in the period of november and december of 2017. Bars represent mean $(n=4$ plants $) \pm$ standard deviation. 

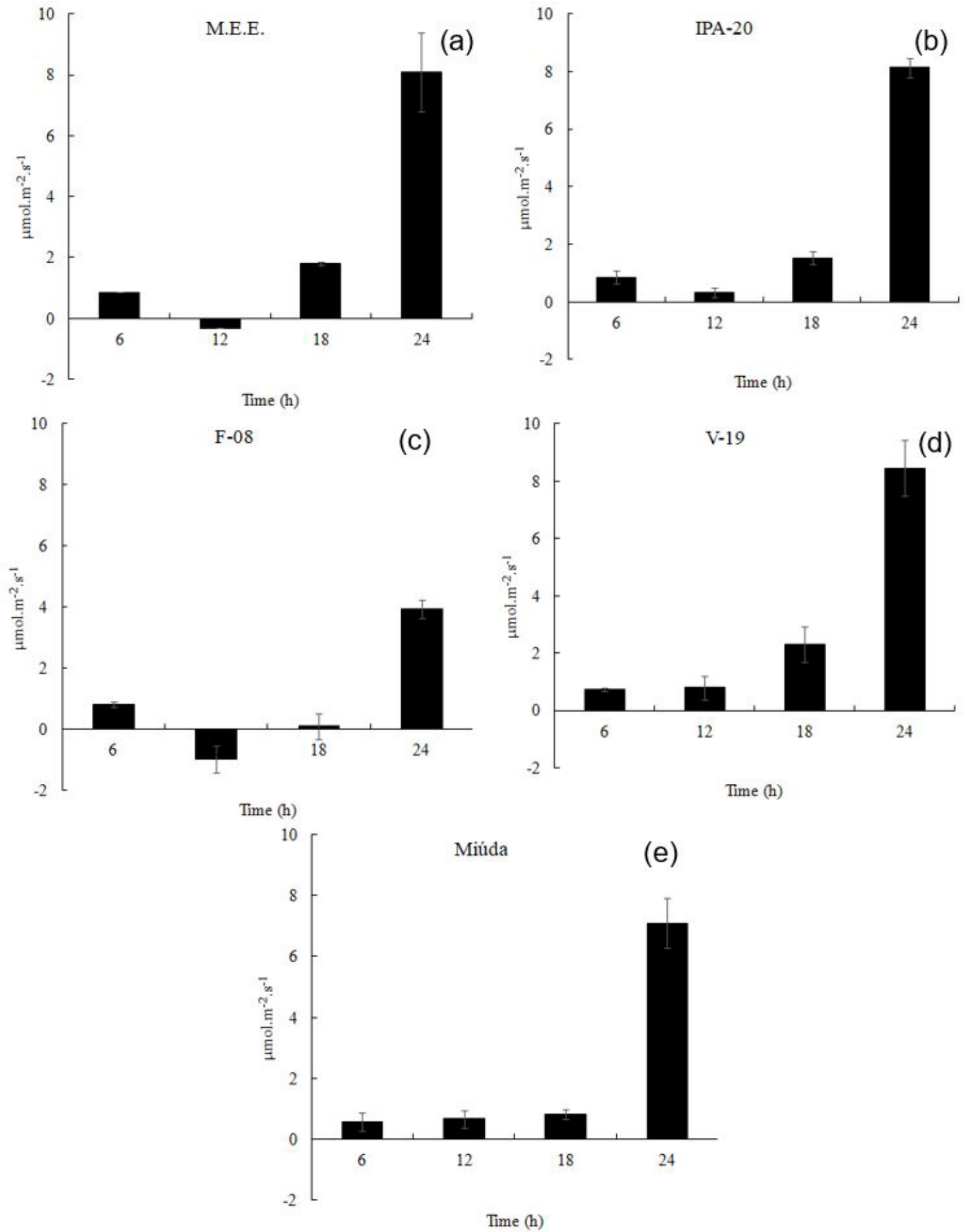

Figure 3. Daily net photosynthesis rate (Pn) of forage cactus varieties Mexican Elephant Ear - M.E.E. - IPA-200016 (O. stricta) (a), IPA clone 20 - IPA-100003 (O. ficus - indica) (b), F-08 - IPA-200008 (O. atropes) (c), V-19 - IPA-200149 (O. larreri) (d) and Miúda - IPA-100004 (N. cochenillifera) (e), grown under screen and irrigation, in the municipality of Arcoverde, Pernambuco, Brazil in the period of november and december of 2017. Bars represent mean $(\mathrm{n}=4$ plants $) \pm$ standard deviation. 
The $\mathrm{CO}_{2}$ atmospheric capture is not observed in forage cactus (O. ficus - indica) at photosynthetic photon flux (PPF) values below 2 mol.m ${ }^{-2}$.day ${ }^{-1}$. At such values, a small amount of $\mathrm{CO}_{2}$ is released into the environment through respiration within 24 hours. Capture of $\mathrm{CO}_{2}$ occurs when there is an increase greater than $2 \mathrm{~mol}^{-2} \mathrm{~m}^{-2}$ day ${ }^{-1}$ in PPF, reaching $50 \%$ of maximum uptake at 13 mol. $\mathrm{m}^{-2}$.day ${ }^{-1}$ and $90 \%$ at $222 \mathrm{~mol}^{-2} \mathrm{may}^{-1}$; saturation at $\mathrm{CO}_{2}$ uptake occurs at an PPF of 30 mol.m ${ }^{-2}$.day ${ }^{-1}$ (NOBEL, 2001).

Transpiration rate $(E)$ ranges from $0.04 \mathrm{mmol} . \mathrm{m}^{-2} \cdot \mathrm{s}^{-1}(6 \mathrm{a}$.m. $)$ to 0.15 mmol. $\mathrm{m}^{-2} \cdot \mathrm{s}^{-1}$ (12 p.m.) - IPA-200016; from 0.03 mmol. $\mathrm{m}^{-2} \cdot \mathrm{s}^{-1}$ (6 p.m.) to 0.09 mmol.m. ${ }^{-2} \cdot \mathrm{s}^{-1}$ (12 p.m.) - IPA-100003; from $0.03 \mathrm{mmol} . \mathrm{m}^{-2} \mathrm{~s}^{-1}\left(6 \mathrm{p} . \mathrm{m}\right.$.) to $0.13 \mathrm{mmol} \cdot \mathrm{m}^{-2} . \mathrm{s}^{-1}$ (12 p.m.) - IPA200008; $0.03 \mathrm{mmol} \cdot \mathrm{m}^{-2} . \mathrm{s}^{-1}$ (6 a.m.) to $0.14 \mathrm{mmol} \cdot \mathrm{m}^{-2} . \mathrm{s}^{-1}(12$ p.m.) - IPA-200149; and from $0.03 \mathrm{mmol} . \mathrm{m}^{-2} \mathrm{~s}^{-1}$ (6 p.m.) to 0.22 mmol. $\mathrm{m}^{-2} \cdot \mathrm{s}^{-1}$ (0 a.m.) - IPA-100004 (Figure 4).

The transpiration rate was practically the same for all palm varieties. Except for the IPA-100004 which has the highest transpiration among the varieties at 0:00 a.m. (Figure 4).

Transpiration occurs during the day in this work, with higher values at night, when temperatures are milder and at noon, when temperatures are higher (Figures 1 and 4). Similar results were found by Gerwick and Williams (1978) when studying the gas exchange of $O$. polyacantha plants, in which transpiration occurs during the day, with maximum values at midnight and noon.

According to Nobel (2001), transpiration of forage cactus (O. ficus - indica) occurs predominantly at night, with maximum values exceeding $1.0 \mathrm{mmol} \cdot \mathrm{m}^{-2} . \mathrm{s}^{-1}$ (9 p.m.). During the daytime, transpiration occurs at very low values, close to zero (9:00 a.m. to 3:00 p.m.). In addition, Whiting and Campbell (1984), report diurnal transpiration rates in irrigated $O$. aurantiaca plants. The highest rates of water vapor efflux occur at night (8:00 pm to 8:00 a.m.), and the lowest during the day (11:00 am to 2:00 pm). Although palm plants transpire during the day, the values are much lower than those reported for $\mathrm{C} 3$ and $\mathrm{C} 4$ plants, indicating the high water use efficiency by those plants (SOUSA et al., 2012; RIBEIRO et al., 2012; SILVA et al., 2019).

The daytime profile of stomatal opening depends on air temperature, light, internal $\mathrm{CO}_{2}$ concentration, age of the cladode and plant water status (ACEVEDO et al., 1983; NOBEL, 2001). Transpiration involves the evaporation of water within the photosynthetic organs (cladodes), in which water vapor is saturated. The water vapor content in saturated air increases exponentially with temperature from $6.8 \mathrm{~g} . \mathrm{m}^{-3}$ at $5{ }^{\circ} \mathrm{C}, 17.3 \mathrm{~g} \cdot \mathrm{m}^{-3}$ at $20{ }^{\circ} \mathrm{C}$ and $39.7 \mathrm{~g} \cdot \mathrm{m}^{-3}$ at $35^{\circ} \mathrm{C}$. On the other hand, the water vapor content in the air surrounding the plants (usually unsaturated) does not change much during the day, unless drastic climate changes occur (NOBEL, 2001). When studying the effect of temperature and gas exchange on O. polyacantha plants, Gerwick and Williams (1978), report increased transpiration when daytime and/or nighttime air temperatures are high.

The main factors involved in light-dependent stomata opening are photosynthesis in guard cell chloroplasts and the specific response to blue light. In addition, increases in cell mesophyll photosynthesis reduce intercellular $\mathrm{CO}_{2}$ concentration, and the low intercellular $\mathrm{CO}_{2}$ concentration opens the stomata. Stomata open when light levels reaching the leaf surface increase, and close as light decreases. This light-dependence on stomatal movements has been reported for many species and conditions (TAIZ et al., 2017).

Blue light stimulates both the stomata-specific response to blue light and the guard cell photosynthesis. Stomatic movements stimulated by light are driven by changes in osmotic regulation of guard cells. Blue light stimulates an $\mathrm{H}^{+}$-ATPase in the guard cell plasma membrane, generating an electrochemical gradient that induces absorption of ions. In addition, blue light also stimulates starch degradation and malate biosynthesis, generating simple sugars that osmotically contribute to stomatal opening (HORRER et al., 2016; TAIZ et al., 2017).

The accumulation of sucrose and $\mathrm{K}^{+}$and their counterions within the guard cells results in stomatal opening. The quality of the light may alter the activity of different osmoregulatory routes that modulate stomatal movements. The stomatal opening is mainly associated with $\mathrm{K}^{+}$capture and its closure is associated with a loss of $\mathrm{K}^{+}$and a decrease in sucrose content (TAIZ et al., 2017).

The age of the cladode influences stomatal conductance profile. The two-week old cladodes open their stomata during the day and close them at night, $\mathrm{C} 3$ mode. The maximum (12 p.m.) and minimum ( 6 a.m. to 6 p.m.) water vapor conductances are both relatively high over the day. In six-month old cladodes, it is observed nocturnal stomatal opening and closing during the day, CAM mode, where maximum and minimal water vapor conductances occur between 8 p.m. and 0 a.m. and between 10 a.m. and 6 p.m., respectively. The diurnal pattern is very similar for 2- (two) months and 3- (three) years old cladodes (ACEVEDO et al., 1983).

The tissue water potential did not influence the stomatal conductance in forage cactus until 20 days of drought. However, conductance decreased substantially after 35 to 65 days of drought. The primary influence of water deficit on stomatal opening was delayed opening at night (35 days), opening and reduction in maximum conductance of water vapor at night $(65$ days), with values very close to zero. Drought did not influence much opening of the stomata at dawn (ACEVEDO et al., 1983).

Stomatal conductance ranges from $0.00 \mathrm{mmol} . \mathrm{m}^{-2} \cdot \mathrm{s}^{-1}(6 \mathrm{p} . \mathrm{m}$. to 0 a.m.) to $6.80 \mathrm{mmol} . \mathrm{m}^{-2} . \mathrm{s}^{-1}$ (12 p.m.) - IPA-200016; from $0.00 \mathrm{mmol} \cdot \mathrm{m}^{-2} \cdot \mathrm{s}^{-1}$ (6 a.m. and 0 a.m.) to $8.44 \mathrm{mmol} \cdot \mathrm{m}^{-2} \cdot \mathrm{s}^{-1}$ $(12: 00 \mathrm{~h})-I P A-100003$; from $0.00 \mathrm{mmol} \cdot \mathrm{m}^{-2} \cdot \mathrm{s}^{-1}(6 \mathrm{p} . \mathrm{m}$. and $0 \mathrm{a} . \mathrm{m} . \mathrm{h})$ to $6.72 \mathrm{mmol} \cdot \mathrm{m}^{-2} \cdot \mathrm{s}^{-1}$ (12 p.m.) - IPA-200008; $0.00 \mathrm{mmol} . \mathrm{m}^{-2} . \mathrm{s}^{-1}$ (6 a.m. and $0 \mathrm{a} . \mathrm{m}$.) to $11.64 \mathrm{mmol} \cdot \mathrm{m}^{-2} \cdot \mathrm{s}^{-1}(12$ p.m.) - IPA-200149; and from $0.00 \mathrm{mmol} \cdot \mathrm{m}^{-2} \cdot \mathrm{s}^{-1}(6 \mathrm{a} . \mathrm{m}$. and 0 a.m.) to $7.99 \mathrm{mmol} \cdot \mathrm{m}^{-2} \cdot \mathrm{s}^{-1}$ (12 p.m.) - IPA-100004 (Figure 5).

Stomatal conductance is the loss of water through leaf or cladode. In addition, it is directly related to the size of the stomatal opening. High evaporation rates and/or high transpiration rate of a plant indicate a high stomatal conductance. Other environmental factors influence stomatal conductance, such as air humidity, soil water content, light intensity, $\mathrm{CO}_{2}$ concentration and temperature (BUCKLEY, 2017). In addition to them, some physiological and genetic factors may also influence the conductance of gases such as cladode age, 

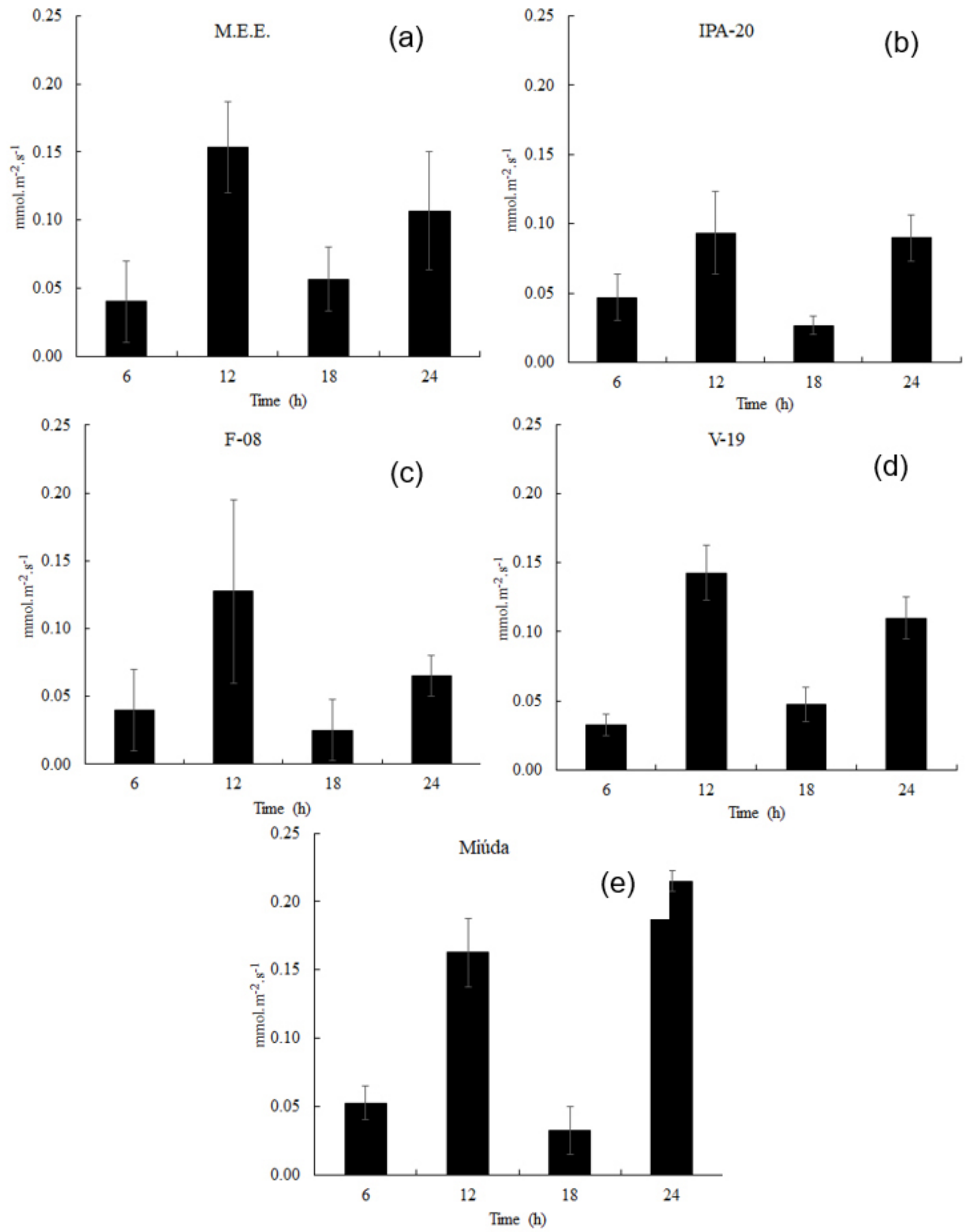

Figure 4. Daily transpiration rate (E) of forage cactus varieties Mexican Elephant Ear - M.E.E. - IPA-200016 (O. stricta) (a), IPA clone 20 - IPA-100003 (O. ficus - indica) (b), F-08 - IPA-200008 (O. atropes) (c), V-19 - IPA-200149 (O. larreri) (d) and Miúda - IPA-100004 (N. cochenillifera) (e), grown under screen and irrigation, in the municipality of Arcoverde, Pernambuco, Brazil in the period of november and december of 2017. Bars represent mean $(\mathrm{n}=4$ plants $) \pm$ standard deviation. 

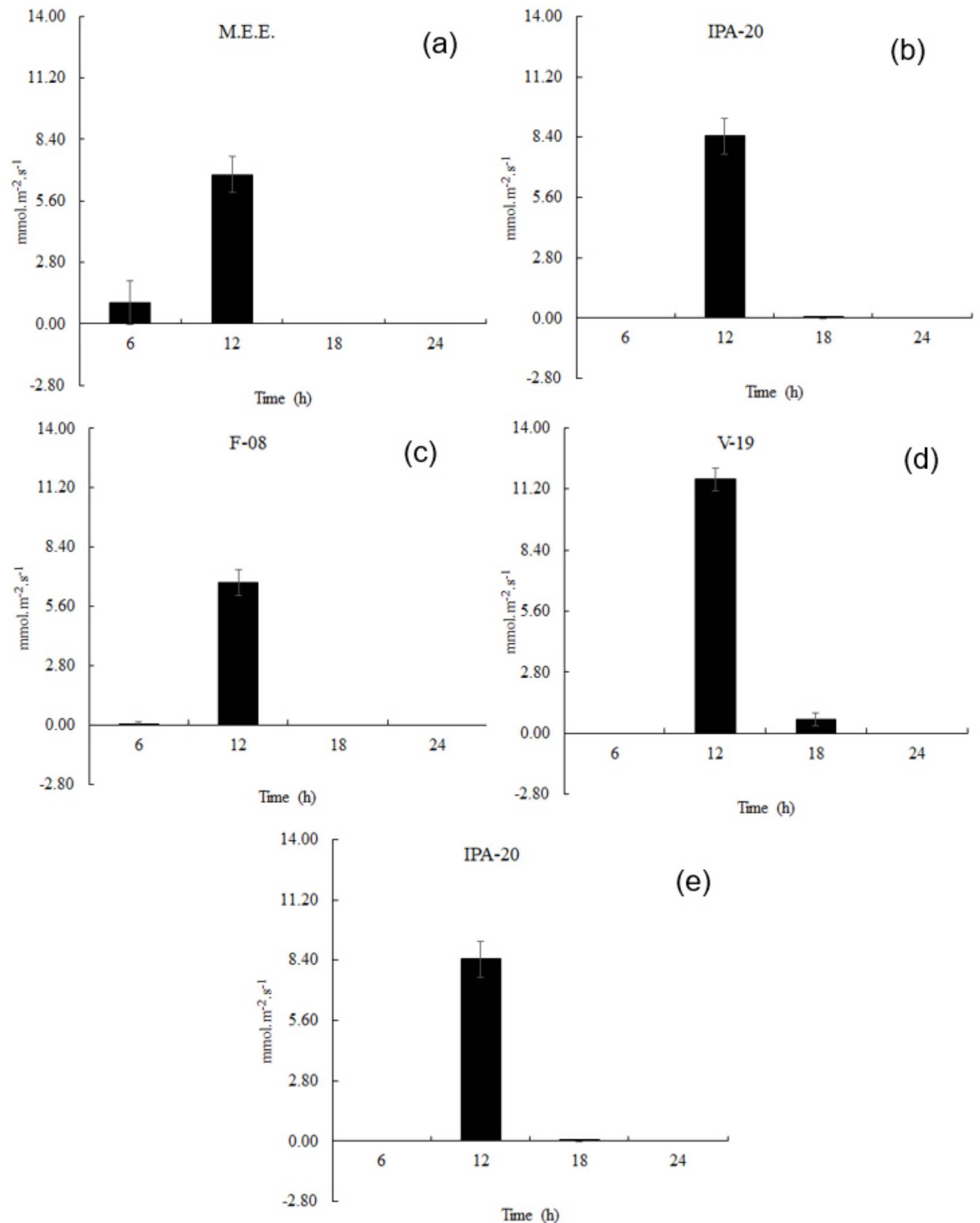

Figure 5. Daily stomatal conductance rate $(C)$ of forage cactus varieties Mexican Elephant Ear - M.E.E. - IPA-200016 (O. stricta) (a), IPA clone 20 - IPA-100003 (O. ficus - indica) (b), F-08 - IPA-200008 (O. atropes) (c), V-19 - IPA-200149 (O. larreri) (d) and Miúda - IPA-100004 (N. cochenillifera) (e), grown under screen and irrigation in the municipality of Arcoverde, Pernambuco, Brazil in the period of november and december of 2017. Bars are the mean $(\mathrm{n}=4$ plants $) \pm$ standard deviation. 
variety, plant water status and/or cladode, sucrose and ABA, etc. (MEDEIROS et al., 2019).

The stomatal opening usually varies in response to changes in light intensity, environment water vapor saturation deficit, and soil moisture availability. As the size of the stomata opening changes, the rates of photosynthesis and transpiration also vary, because the size of the pores (stomata) will provide a resistance corresponding to the an inward diffusion of $\mathrm{CO}_{2}$ and $\mathrm{H}_{2} \mathrm{O}$ out of the leaf or cladode. The inverse of this resistance can be considered as the conductance of these two gases across a leaf surface (BUCKLEY, 2017).

Thus, conductance can be considered in parallel or in series. Moreover, it is obtained by measuring transpiration and leaf surface temperature $\left({ }^{\circ} \mathrm{C}\right)$ by applying reliable equations (LEINONEN et al., 2006; BUCKLEY, 2017). However, some phenomenological aspects of stomatal behavior in some seedless plants remain unsolved, such as the responses to $\mathrm{CO}_{2}$ and abscisic acid concentration (BUCKLEY, 2017).

The conductance pattern found in this work differs from those reported for CAM plants, where the conductance is null during the day and positive at night (TAIZ et al., 2017). In this study, the conductance in the early morning, late afternoon and night are null, and positive during the day (Figure 5). This stomatal conductance pattern is identical to those reported for $\mathrm{C} 3$ and C4 plants (NOBEL, 2001; TAIZ et al., 2017).

The absence of stomatal conductance detection at night, in the early morning and late afternoon is probably due to the lack of variation in water loss and/or no variation in stomatal opening at measurement. Air temperature and cladodes at these periods were mild, air humidity was high, and the absence or insufficiency of active photosynthetic radiation was observed in promoting a change in the water potential of guard and subsidiary cells (Figures 1 and 2). Indeed, the variation in water vapor pressure (WVP) was null or negative at these hours (data not shown).

However, at noon, when the temperatures and active photosynthetic radiation were maximum, the conductance was positive (Figures 1, 2 and 5). At this time, an increase in plant transpiration was observed (Figure 4), which was possibly due to the reduction in cladode temperature. In addition, the variation in water vapor pressure (WVP) at this time was positive (data not shown).

Many studies correlate stomatal conductance with stomatal opening, $\mathrm{CO}_{2}$ assimilation and transpiration. Pimienta-Barrios et al. (2005a, b), when studying the gas exchange of forage cactus (O. ficus - indica) cladodes in irrigated and dry conditions, found no significant correlation between stomatal conductance and $\mathrm{CO}_{2}$ assimilation when plants were under water stress. However, when plants were irrigated, positive correlations between stomatal conductance and $\mathrm{CO}_{2}$ assimilation were reported. Pimienta-Barrios et al. (2000), report no relationship between stomatal conductance and $\mathrm{CO}_{2}$ assimilation at some times of the year for these CAM plants when studying the gas exchange in O. ficus - indica and pitaya (Stenocereus queretaroensis).

Some CAM plants are able to increment total photosynthesis during wet conditions by fixing $\mathrm{CO}_{2}$ via the Calvin-Benson cycle at the end of the day when temperature gradients are less extreme. Other species may use the CAM strategy as a survival mechanism during severe water limitations. Opuntia cladodes can survive for several months without water after detachment from the mother- plant. Their stomata remain closed at all times, and the respiration-released $\mathrm{CO}_{2}$ is refixed to malate. This process has been denominated idle CAM and allows the plant to survive long periods of drought with extremely reduced water loss (TAIZ et al., 2017).

In fact, in a study conducted with forage cactus cladodes, IPA-200016 (O. stricta) and IPA-200205 (N. cochenillifera) detached from the mother-plant, managed to survive for a period of twelve months before planting under laboratory conditions without losing cladode moisture (unpublished data).

Most stomatal conductance models are based on physiological mechanisms that simulate two key-variables: guard cell volume, or turgor pressure; and osmotic contents of guard cells, or osmotic pressure. The explanation for this approach is that stomatal opening occurs when the guard cell expands in volume (FRANKS et al., 2001). Changes in guard cell volume often result in osmotic water movements driven by regulation of active ion transport, and carbon metabolism in guard cells. In addition, guard cell water movements can also occur passively as a result of changes in local water potential.

The volume of the guard cell, or turgor, is usually predicted from the mass balance; that is, by assuming that water potential is dictated by a stable balance between water supply from other parts of the leaf or the plant and evaporated water loss into the atmosphere. Water balance may also predict the effects of turgor on epidermal cells from adjacent or subsidiary areas, whose "back-pressure" opposes stomatal opening (VIALETCHABRAND et al., 2017).

Several improvements have emerged in recent years in the basic conceptual framework for modeling based on stomatal conductance processes. These advances mainly involve three areas: improved understanding of stomatal hydro-mechanical diversity and its role in water stress responses; growing awareness of the multiplicity of underlying mechanisms of stomatal responses to both light and $\mathrm{CO}_{2}$, including the role of mesophyll photosynthesis; and advances in modeling based on kinetics of osmotic pressure and guard-cell volume (FRANKS et al., 2001).

The daily profile of $\mathrm{CO}_{2 \text { int }}$ of forage cactus varieties followed the same response pattern, except for IPA-100003, IPA-200008 and IPA-100004. In the IPA- 100003 variety, $\mathrm{CO}_{2 i n t}$ was observed only at 12 p.m. On the other hand, in IPA-200008 and IPA-100004, $\mathrm{CO}_{2 \text { int }}$ was observed at 6 p.m. (Figure 6). Values of $\mathrm{CO}_{\text {2int }}$ range from $0.00 \mathrm{mmol} \cdot \mathrm{m}^{-2} \cdot \mathrm{s}^{-1}(6 \mathrm{p} . \mathrm{m}$. and 0 a.m.) to $836.65 \mathrm{mmol} . \mathrm{m}^{-2} . \mathrm{s}^{-1}$ (12 p.m.) - IPA-200016; from $0.00 \mathrm{mmol} . \mathrm{m}^{-2} . \mathrm{s}^{-1}$ (6 a.m., $6 \mathrm{p} . \mathrm{m}$. and 0 a.m.) to $620.04 \mathrm{mmol} . \mathrm{m}^{-2} \cdot \mathrm{s}^{-1}$ (12 p.m.) - IPA-100003 ; from 0.00 mmol.m ${ }^{-2} . \mathrm{s}^{-1}(0$ a.m.) to 593.99 mmol.m. ${ }^{-2} \mathrm{~s}^{-1}(12 \mathrm{p} . \mathrm{m}$.$) - IPA-200008; 0.00 \mathrm{mmol} \cdot \mathrm{m}^{-2} \cdot \mathrm{s}^{-1}(6$ p.m. and 0 a.m.) at 286.54 mmol.m-2. s $^{-1}(12$ p.m. ) - IPA-200149; and from $0.00 \mathrm{mmol} \cdot \mathrm{m}^{-2} \cdot \mathrm{s}^{-1}\left(0 \mathrm{a} . \mathrm{m}\right.$.) to $427.41 \mathrm{mmol} \cdot \mathrm{m}^{-2} \cdot \mathrm{s}^{-1}(12$ p.m.) - IPA-100004 (Figure 6).

The high $\mathrm{CO}_{2 \text { int. }}$ values in photosynthetic tissues of CAM plants, such as $O$. ficus - indica, is related to higher carboxylation efficiency to decrease stomatal conductance. The increase in 

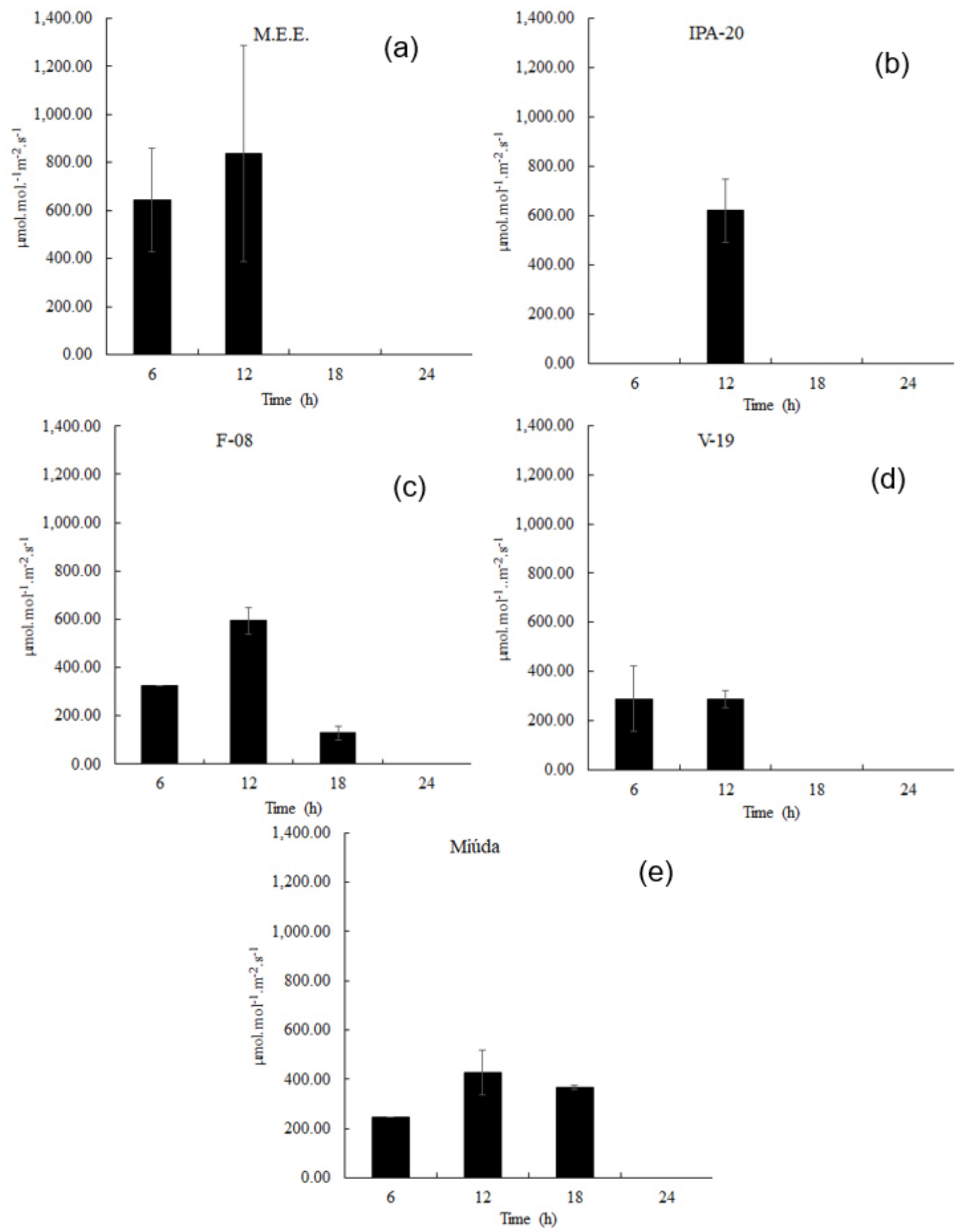

Figure 6. Daily internal $\mathrm{CO}_{2}$ concentration rate $\left(\mathrm{CO}_{2 \text { int. }}\right)$ of forage cactus varieties Mexican Elephant Ear - M.E.E. - IPA-200016 (O. stricta) (a), IPA clone 20 - IPA- 100003(O. ficus - indica) (b), F-08 - IPA-200008 (O. atropes) (c), V-19 - IPA-200149 (O. larreri) (d) and Miúda - IPA-100004 (N. cochenillifera) (e), grown under screen and irrigation, in the municipality of Arcoverde, Pernambuco, Brazil in the period of november and december of 2017. Bars represent mean $(n=4$ plants $) \pm$ standard deviation. 
$\mathrm{CO}_{2 \text { int. }}$ following the reduction in $\mathrm{CO}_{2}$ absorption is related to a rise in respiration as a consequence of physiological stress caused by the combined effects of low soil water content, high temperatures, and development of puppy-cladodes (PIMIENTA-BARRIOS et al., 2005a, b).

Furthermore, the failure to detect internal concentrations of $\mathrm{CO}_{2}$ in the forage cactus cladodes at night (Figure 6) is an indicative of the fixation of atmospheric and respiratory $\mathrm{CO}_{2}$ in oxalacetate using phosphoenolpyruvate produced by glycolytic decomposition of stored carbohydrates and/or produced during the day. Oxalacetate via the enzyme NADP-malate dehydrogenase is then converted to malate, which is stored in vacuoles for the rest of the night (TAIZ et al., 2017).

At the presence of light, concentrations of internal $\mathrm{CO}_{2}$ increase in the palm (Figure 6), an indication that decarboxylation of malate stored at night is occurring. During the day, the malate leaves the vacuoles and is rapidly decarboxylated via cytosolic NADP-ME or mitochondrial NAD-ME, releasing $\mathrm{CO}_{2}$ to the chloroplasts to be fixed by rubisco into the three-carbon acid (C3), and then to starch or sucrose via gluconeogenesis (TAIZ et al., 2017).

The average WUE values significantly differ in relation to time and varieties. However, no significant difference was detected between varieties due to the high variability of responses between cladode orders (Figure 7). The varieties V-19 (IPA-200149), MEE (IPA-200016) and IPA clone 20 (IPA-100003) tend to be the most efficient in water use compared to the others.

The high efficiency in water use helps to solve shortage issues, reduce conflicts between users, increase stability and guarantee the production, especially in regions where there is occurrence of droughts or rainfall distribution is irregular. Thus, the high efficiency in the use of water by forage cactus compared to other plants makes it a widely cultivated species in arid and semiarid regions for various productive purposes (FAGGION et al., 2009; ALVES et al., 2017).
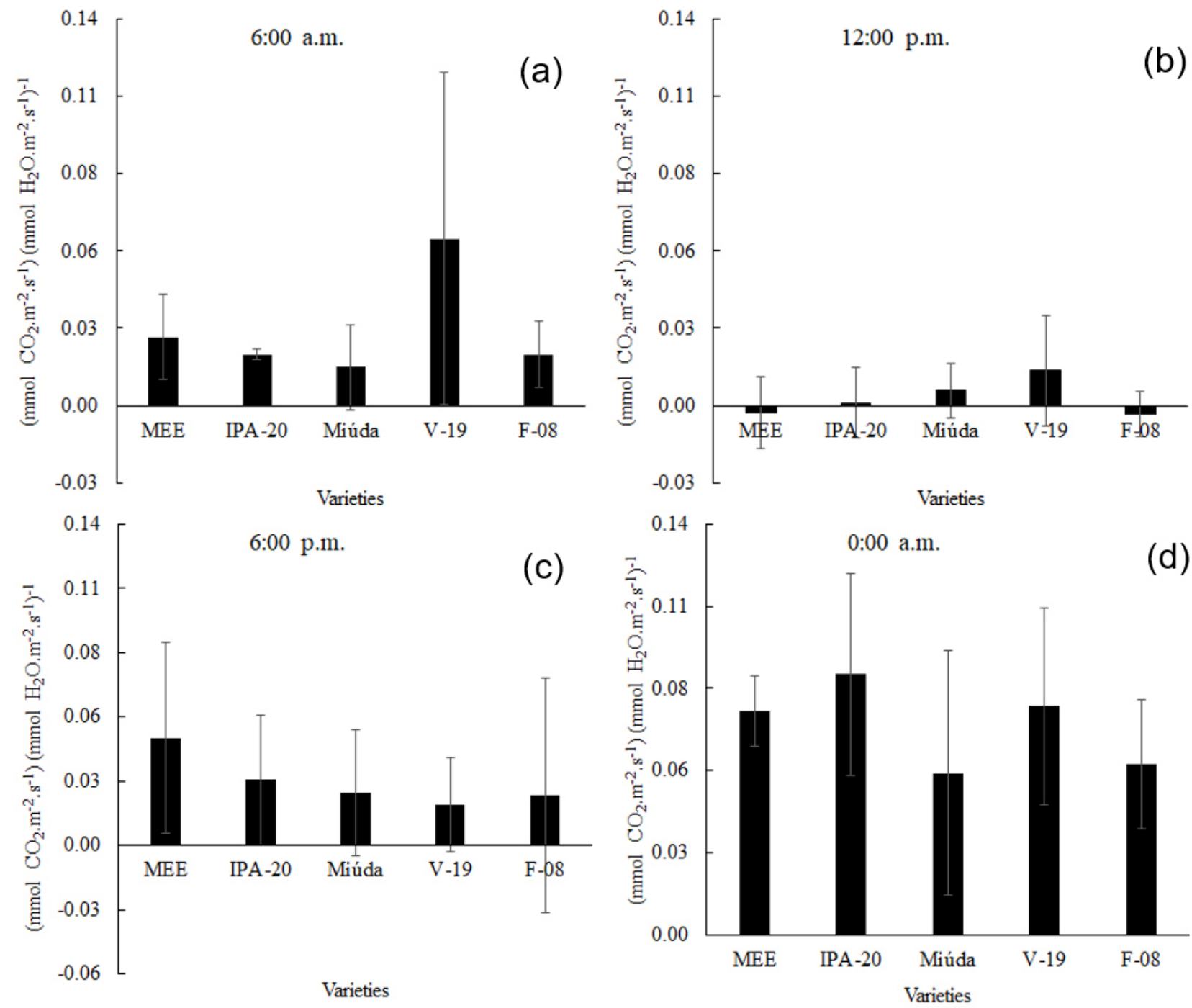

Figure 7. Water use efficiency (WUE) at 6:00 a.m. (a), 12:00 p.m.(b), 6:00 p.m. (c) and 0:00 a.m. (d) of forage cactus varieties Mexican Elephant Ear - M.E.E. - IPA- 200016 (O. stricta), IPA clone 20 - IPA-100003 (O. ficus - indica), F-08 - IPA-200008 (O. atropes), V-19 - IPA-200149 (O. larreri) and Miúda - IPA-100004 (N. cochenillifera), grown under screen and irrigation in the municipality of Arcoverde, Pernambuco, Brazil in the period of november and december of 2017. 
The highest $C E i$ in palm varieties occurs early in the morning (6 a.m.) and at noon, daytime pahse. No $C E i$ were observed between varieties in the late afternoon $(6 \mathrm{p} . \mathrm{m}$.) and night $(0: 00$ a.m.). The V-19 variety (IPA-200149) was the most efficient in carboxylation in comparison to the others. However, no significant differences were observed between varieties due to the high variability of responses between orders of cladode (Figure 8).

The changes observed in $\mathrm{CO}_{2}$ capture rate and the regulation of enzymes involved in the process throughout the day create a 24-hour CAM cycle. In the cellular environment, four distinct phases are observed in controlling the carboxylations. In phase I (night), the stomata are open and the atmospheric and respiratory $\mathrm{CO}_{2}$ are fixed in malate. During this period, the phosphoenolpyruvate carboxylase (PEPCase) enzyme catalyzes the reaction of phosphoenolpyruvate and $\mathrm{HCO}_{3}^{-}$resulting in oxalacetate. The conversion of oxalacetate to malate is performed by means of a NADP-malate dehydrogenase during this same period. In phase III (daytime), the stomata are closed and the cladodes are photosynthesizing, the stored malate is decarboxylated. In this phase, the concentration of $\mathrm{CO}_{2}$ around the active site of rubisco is high. Phases II (early morning) and IV (late afternoon) are transient and alter metabolism in preparation for the other phases (TAIZ et al., 2017).

In phase II, rubisco activity increases but decreases in phase IV. On the other hand, PEPCase activity increases in phase IV, but decreases in phase II. The contribution of each phase to the global carbon balance varies considerably between varieties within the same species, and between different CAM plant species. Moreover, these phases are sensitive to environmental conditions (irradiation, temperature, relative humidity, soil water content), and ontogenetic factors, causing great variability of responses between and within the same individual (PIMIENTABARRIOS et al., 2005a, b; TAIZ et al., 2017).

Pimienta-Barrios et al. (2005a, b), report the interference of young cladodes on gas exchange of basal cladodes in
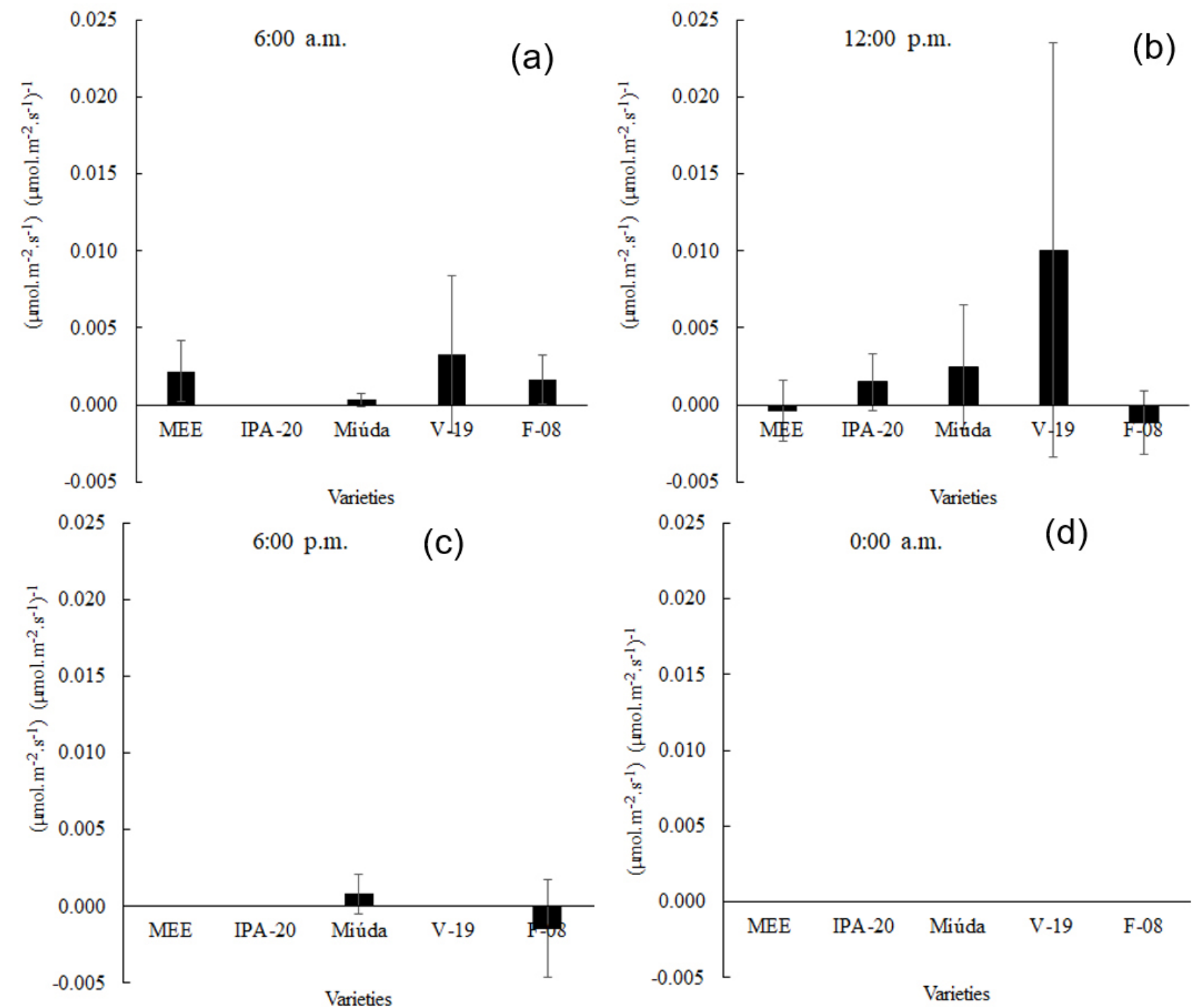

Figure 8. Instantaneous carboxylation efficiency (CEi) at 6:00 a.m. (a), 12:00 p.m.(b), 6:00 p.m. (c) and 0:00 a.m. (d) of forage cactus varieties Mexican Elephant Ear - M.E.E. - IPA-200016 (O. stricta), IPA clone 20 - IPA-100003 (O. ficus - indica), F-08 - IPA-200008 (O. atropes), V-19 - IPA-200149 (O. larreri) and Miúda - IPA-100004 (N. cochenillifera), grown under screen and irrigation, in the municipality of Arcoverde, Pernambuco, Brazil in the period of november and december of 2017. 
O. ficus - indica grown under irrigated and dry conditions. The net $\mathrm{CO}_{2}$ assimilation and the chlorophyll content of the basal cladodes is significantly reduced as the number of young cladodes increases in both wet and dry conditions. In addition, CAM phase expression in basal cladodes is affected by young cladodes in both conditions (dry and wet). The authors also report a reduction in the relative water content and an increase in the internal concentration of $\mathrm{CO}_{2}$ in the basal cladodes when plants are subjected to water stress.

Documented studies indicate a shift from C3 to CAM photosynthesis during the development of forage cactus cladodes. In the context of the evolution and functional significance of CAM, the observations support the argument that constitutive and/or optional CAMs are merely extreme or continuous terms of variation of CAM expressions, which are totally controlled by ontogeny through the expression of genes induced or suppressed by water and/or saline stress. Thus, optional or constitutive CAM plants are not exclusive (WINTER et al., 2011).

Constitutive CAM plants use night $\mathrm{CO}_{2}$ capture at all times, while optional-CAM plants turn to CAM pathway only when induced by water or saline stress (LIGUORI et al., 2013; TAIZ et al., 2017).

\section{Conclusion}

Forage cactus varieties (IPA-200016 - O. stricta, IPA-100003 - O. ficus - indica, IPA-200008 - O. atropes, IPA-200149 - O. larreri and IPA-100004 - N. cochenillifera) has the same net photosynthesis pattern, transpiration rate, stomatal conductance, internal $\mathrm{CO}_{2}$ concentration, efficiency in water use and carboxylation.

Gas exchange of forage cactus (Opuntia and Nopalea) takes place at day time in the optional-CAM mode. The highest rates of net $\mathrm{CO}_{2}$ assimilation occur at night (CAM). Transpiration rates occur at daytime (CAM-C3). The stomatal conductance is identical to those reported for plants $\mathrm{C} 3$ and $\mathrm{C} 4$.

The V-19 (IPA-200149) variety tends to be the most efficient in water use and carboxylation in relation to the others.

\section{Acknowledgements}

Authors thank the Agronomic Institute of Pernambuco (IPA) and the Secretary of Agriculture and Agrarian Development of Pernambuco State for funding the research.

\section{References}

ACEVEDO, E.; BADILLA, I.; NOBEL, P. S. Water relations, diurnal acidity changes, and productivity of a cultivated cactus, Opuntia ficus-indica. Plant Physiology, Minneapolis, v. 72, n. 3, p. 775-780, 1983.

ALVES, F. A. L. et al. Study of the genetic variability, correlation and importance of phenotypic characteristics in cactus pear (Opuntia and Nopalea). African Journal of Agricultural Research, Nigeria, v. 11, n. 31, p. 2849-2859, 2016.

ALVES, F. A. L. et al. Chemical and nutritional variability of cactus pear cladodes, genera Opuntia and Nopalea. American Journal of Food Technology, New York, v. 12, n. 1, p. 25-34, 2017.
BUCKLEY, T. N. Modeling stomatal conductance. Plant Physiology, Minneapolis, v. 174, n. 2, p. 572-582, 2017.

FAGGION, F.; OLIVEIRA, C. A. S.; CHRISTOFIDIS, D. Uso eficiente da água: uma contribuição para o desenvolvimento sustentável da agropecuária. Pesquisa Aplicada \& Agrotecnologia, Guarapuava, v. 2, n. 1, p. 187-190, 2009.

FRANKS, P. J. et al. Guard cell volume and pressure measured concurrently by confocal microscopy and the cell pressure probe. Plant Physiology, Minneapolis, v. 125, n. 4, p. 1577-1584, 2001.

GERWICK, B. C.; WILLIAMS, G. J. Temperature and water regulation of gas exchange of Opuntia polyacantha. Oecologia, Berlin, v. 35 , n. 2, p. 149-159, 1978.

GÓMEZ, J. M. R. et al. A irradiância solar: conceitos básicos. Revista Brasileira de Ensino de Física, São Paulo, v. 40, n. 3, p. e3312, 2018.

HORRER, D. et al. Blue light induces a distinct starch degradation pathway in guard cells for stomatal opening. Current Biology, London, v. 26, n. 3, p. 362-370, 2016.

INSTITUTO BRASILEIRO DE GEOGRAFIA E ESTATISTICA IBGE. Censo agropecuário 2017. Rio de Janeiro, 2019. Available from: $<$ https://sidra.ibge.gov.br/tabela/6615\#resultado. Access in: 1 Sept 2019.

LEINONEN, I. et al. Estimating stomatal conductance with thermal imagery. Plant, Cell \& Environment, v. 29, n. 8, p. 1508-1518, 2006.

LIGUORI, G. et al. $\mathrm{CO}_{2}$ uptake of Opuntia ficus-indica (L.) Mill. whole trees and single cladodes, in relation to plant water status and cladode age. Italian Journal of Agronomy, Firenze, v. 8, n. 3, p. 14-20, 2013.

MEDEIROS, D. B. et al. Metabolomics for understanding stomatal movements. Theoretical and Experimental Plant Physiology, Cham, v. 31, n. 1, p. 91-102, 2019.

NOBEL, O. S. Biologia ambiental. In: BARBERA, G.; INGLESE, P.; BARRIOS, E. P. (Ed.). Agroecologia, cultivo e usos da palma forrageira. 1st ed. Roma: Food Agriculture Organization of the United Nations/Brazilian Support Service to Micro and Small Entreprises of Paraiba, 2001. cap. 5, p. 36-48.

OLIVEIRA, F. T. et al. Palma forrageira: Adaptação e importância para os ecossistemas áridos e semiáridos. Revista Verde de Agroecologia e Desenvolvimento Sustentável, Mossoró, v. 5, n. 4, p. 27-37, 2010.

PIMIENTA-BARRIOS, E. et al. Ecophysiology of young stems (cladodes) of Opuntia ficus-indica in wet and dry conditions. Gayana. Botánica, Concepcion, v. 69, n. 2, p. 232-239, 2012.

PIMIENTA-BARRIOS, E. et al. Seasonal variation of net $\mathrm{CO}_{2}$ uptake for cactus pear (Opuntia ficus-indica) and pitayo (Stenocereus queretaroensis) in a semi-arid environment. Journal of Arid Environments, London, v. 44, n. 1, p. 73-83, 2000.

PIMIENTA-BARRIOS, E.; ZAÑUDO-HERNÁNDEZ, J.; NOBEL, P. $\mathrm{S}$. Effects of young cladodes on the gas exchange of basal cladodes of Opuntia ficus-indica (cactaceae) under wet and dry conditions. International Journal of Plant Sciences, Chicago, v. 166, n. 6, p. 961-968, 2005a.

PIMIENTA-BARRIOS, E. et al. Young daughter cladodes affect $\mathrm{CO}_{2}$ uptake by mother cladodes of Opuntia ficus-indica. Annals of Botany, London, v. 95, n. 2, p. 363-369, 2005b.

QUEIROZ, M. G. et al. Relações hídrico-econômicas da palma forrageira cultivada em ambiente semiárido. Revista Irriga, Botucatu, v. 1, n. 1, p. 141-154, 2016.

RIBEIRO, R. V. et al. Moderate warm temperature improves shoot growth, affects carbohydrate status and stimulates photosynthesis of sweet orange plants. Brazilian Journal of Plant Physiology, Campinas, v. 24, n. 1, p. 37-46, 2012. 
SILVA, L. K. S. et al. Gas exchange and photochemical efficiency of Caatinga plants submitted to different water management strategies. The Journal of Agricultural Science, Cambridge, v. 11, n. 11, p. 53-69, 2019.

SOUSA, A. E. C. et al. Trocas gasosas e conteúdo de carboidratos e compostos nitrogenados em pinhão-manso irrigado com águas residuária e salina. Pesquisa Agropecuária Brasileira, Brasília, v. 47, n. 10, p. 1428-1435, 2012.

TAIZ, L. et al. Fisiologia e desenvolvimento vegetal. 6. ed. Porto Alegre: Artmed, 2017. 858 p.
VIALET-CHABRAND, S. R. M. et al. Temporal dynamics of stomatal behavior: modeling and implications for photosynthesis and water use. Plant Physiology, Minneapolis, v. 174, n. 2, p. 603-613, 2017.

WHITING, B. H.; CAMPBELL, E. E. Effect of moisture supply on CAM in Opuntia aurantiaca (jointed cactus). South African Journal of Plant and Soil, Pretoria, v. 1, n. 3, p. 87-91, 1984.

WINTER, K.; GARCIA, M.; HOLTUM, J. A. M. Drought-stressinduced up-regulation of CAM in seedlings of a tropical cactus, Opuntia elatior, operating predominantly in the C 3 mode. Journal of Experimental Botany, Oxford, v. 62, n. 11, p. 4037-4042, 2011.

Received: May 01, 2020 Approved: July 20, 2020 